\title{
God and the pandemic: A Christian reflection on the coronavirus and its aftermath by N.T. Wright. Zondervan, 2020
}

\author{
Daniel W. O'Neilla
}

${ }^{a}$ MD, MTh, Assistant Clinical Professor of Family Medicine at the University of Connecticut School of Medicine. Managing Editor, Christian Journal for Global Health

\section{Introduction}

In keeping with the historical tradition of both theological reflection and active engagement in the face of disasters, calamity, or disease, the COVID19 pandemic has elicited an awakening of both deep spiritual questions and innovative effective responses throughout the world. During times of vulnerability, all religions seek to draw from their ancient texts and traditions some profound insight, solace, and inspiration. ${ }^{1}$ Aspects of global human responsibility, the meaning or cause of disease and suffering, and the need for God's comfort and rescue are highlighted amid these challenging times.

This year's responses from within the Christian community have varied. Some have emphasized the sovereignty of God even in his "bitter providence" and the necessity of repentance. ${ }^{2}$ Some offer comfort or fresh apologetics for the veracity of the Christian faith in pluralistic or academic contexts. ${ }^{3}$ Some have been reminded of the historic and normative Christian response to epidemics as a Christian distinction. ${ }^{4}$ Some also highlight the need to protect the vulnerable and marginalized in line with New and Old Testament teaching, to pray, and to retain social but not relational distancing. ${ }^{5,6}$ Others are calling Christians not to forget their moral obligation to follow public health measures for the sake of others. ${ }^{5}$

Theologians and church leaders raising conscientiousness regarding disease and human health, as well as responsibilities for community and global health are very welcome responses. In God and the Pandemic, N.T. Wright presents a brief and concise treatment of some of the contemporary issues the pandemic raises. His purpose in this very readable small (75 page) book is to avoid knee-jerk responses and presuppositions and to keep reactions within a biblical framework. (xi)

\section{Summary}

Wright begins with a critique of some common Western responses such as Stoic passive resignation, Epicurean pleasure seeking and self-preservation, or Platonic spiritual detachment. He takes aim at Christians who assume this is a sign of the end times, or those who foster escapism. He eschews the "blame game", especially when it involves ascribing it to the sin of victims $(5,10)$. He even critiques those who receive the pandemic as a newfound opportunity for evangelism, or who ascribe it to "ancient pagan theories" of retributive destructive acts of an angry deity (6).

As a corrective to what he would describe as misunderstandings or misapplications, he begins in Chapter 2 to trace the Deuteronomic biblical story of Israel and God's "healing, rescue, restoration, and new creation following after a time not only of judgment but of despair." (14) This is manifest in the example of the Babylonian captivity followed by the regathering. In his brief Old Testament interpretive framework, Wright recognizes the deeper story of the good creation and the "dark power that has from the start tried to destroy God's good handiwork," (14) but remains agnostic toward that unknowable dark power. His main thesis is that the response to a pandemic like COVID-19 is mainly to lament, complain, state the case, and leave the results with God. (14) 
In Chapter 3, he addresses Jesus and the Gospels as this "healing after judgment" story line is now (in a new way) carried through into the central biblical story of Jesus' healing and redeeming work, culminating in his resurrection. He contrasts the signs of the kingdom of God as signs of new creation, forward-looking signs, instead of looking back at hypothetical causes and calling for retributive destruction (16-17). Instead, following Jesus' kingdom-oriented approach is to start with tears and groans of lament, then to look forward to see what God is going to do about it. The authority of Jesus' reign was given in power at the resurrection/ascension and salvation continues to spread, with the central sign for all nations being the resurrection, appropriated through the suffering servant's crucifixion. In the gospels, a new notion of power is presented, and a new way of taking dominion through weeping, suffering, prayer and trust. He calls for providence and atonement to be kept together. (28)

In Chapter 4 Wright gives a further perspective on reading the New Testament which is "all about restoring creation the way it was meant to be. God always wanted to work in this world through loyal human beings." (32) He identifies a call to repentance not because of any subsequent events such as famines or plagues but because of Jesus himself. (37) In an exposition of Romans 8, he emphasizes the Christians' responsibility to groan with all of creation, lamenting and weeping with the suffering, "at the point where the world is in pain" (45), then praying for renewal, healing and reconciliation. He then calls for courageously and sacrificially joining with God (synergeo Rom 8:28) in bringing it about in the here and now, which God does creatively through human agency, "creating a context for the multiple works of healing and hope . . tears and toil, lament and labor." (51)

Finally, in Chapter 5 Wright presents a direct application of the thesis of the book to the present pandemic. He wants to keep central the narrative of renewal after devastation, of the singular sign of Christ's resurrection, and the starting point of humble lament. Understanding evil as an intrusion into God's creation, he warns that it's like putting "wind in a bottle" to spend time analyzing what evil is, why it's allowed or what God does with it - other than that he overcomes it through Jesus' atoning death. (57) He calls for practical responsibility as stewards of creation for "proper investigation and accountability" for whatever caused the virus to leak out and spread. (58) Signs of new life erupt in the presence of faithful people, with indiscriminate and fearless care for those in communities, including hospitals and hospices, the mark of the early church and throughout her history. (62) "Out of lament must come fresh action," as "sign-producers for God's kingdom." (64) This includes holding world leaders to account and for the church to not abrogate her responsibility for medical work, which is part of its long track record. (66) Wright's answer to "Where is God in the pandemic?" is this: "Out there on the front line, suffering and dying to bring healing and hope." (68) This is the healing presence of Jesus himself.

He finishes the book likening the lockdowns and pandemic precautions as a time of exile like in Babylon where the people of God are never quite satisfied but nevertheless seek the welfare of the city, longing for a return to Jerusalem. (71) Our political leaders' "acrimonious dialogue of the deaf" (72) emerges when death and economic down turn are seen as the worst possible outcomes. He calls for Psalm 72 to consider the disproportionate effect the pandemic has on the poor, hoping for new creation to come to birth. With "vision and realism," seeing "new signs of genuine new possibilities, new ways of working which will regenerate old systems and invent new and better ones, which we could then recognize as forward-looking hints of new creation." (75)

\section{Review}

N.T. Wright has once again, in a memorable and persuasive fashion and in short order generated a theological reflection to a contemporary issue weighing heavily on people's minds. His critiques 
against the extremes of perspectives or responses are well founded, but may not be as generous as would be fitting a unified global Christian community, whose diversity might capture the greater grandeur of God, contextualized for deep localized meaning. $\mathrm{He}$ recognizes the reality of resident evil, not denying its existence as some higher criticism theologians and materialists often do. Yet he takes an agnostic approach instead of an interventionist approach to evil, which Pentecostal streams might find evasive. His main thesis starts as more pastoral (lament, weep, comfort, pray and hope) than what might drive a scientist, clinician, or activist to engage with solving problems in the physical or social or political realms. However, he does get to the latter eventually, which ends up appealing as much to the nurse, researcher or public health specialist as it does to the pastor.

Wright captures the oft-forgotten sign of suffering as an identification with the "one-off death of the Messiah" (38) and creatively balances that with the glory to be revealed in the eschaton pictured in Revelation 21, as a "final move in a longer sequence." (40) That longer sequence is manifest in the ongoing work of transformational development and global health promotion many of us engage in among the suffering, which Wright says grows out of lament (50) and is a sign of God's coming with new life and health as part of this glorious continuum. The insightful and non-technical framework shared in this book encourages readers from all disciplines to follow Christ's example, acknowledge his presence, embrace suffering if needed, pray fervently for restoration, engage in meaningful redemptive work, and look with hope to the renewal of all things. God and the Pandemic contributes significantly to filling the literature gap between theology and heath, and creating a very accessible and much-need convergence to tackle the devastating effects of this disease with meaning, purpose and tear-streaked hope..

\section{References}

1. Xiong J, Isgandarova N, Panton A. COVID-19 demands theological reflection: Buddhist, Muslim, and Christian perspectives on the present pandemic. International Journal of Practical Theology 24(1), July 2020. 5-28. https://doi.org/10.1515/ijpt-2020-0039

2. Lennox JC. Where Is God in a coronavirus world? Epsom, Surrey, England: The Goodbook Company, 2020.

3. Piper, John. Coronavirus and Christ. Wheaton: Crossway, 2020.

4. Just B. Historic plagues and Christian responses: Lessons for the church today? Christian Journal for Global Health. April 2020;7(1):7-12 https://doi.org/10.15566/cjgh.v7i1.373

5. Stetzer E. Removing the coronavirus mask: may this crisis reveal us as Christians. USA Today, 19 March 2020. [Internet] Available from:

https://www.usatoday.com/story/opinion/2020/03/19 /during-pandemic-cornoavirus-christians-act-asjesus-taught-column $/ 5055427002$

6. Sims, S. Care and compassion during COVID-19. Matthiasmedia. [Internet] Available from: https://matthiasmedia.com.au/blogs/news/care-andcompassion-during-covid-19

7. Gabriele M. Christian groups that resist public-health guidelines are forgetting a key part of the religion's history. Time. 20 April, 2020. [Internetr] Available from: https://time.com/5824128/early-christiancaritas-coronavirus/

Submitted 30 Oct 2020, accepted 3 Nov 2020, published 9 Nov2020

Competing Interests: None declared. Correspondence: Dr. Daniel O'Neill, Connecticut, USA. dwoneill@cigh.org

Cite this article as: O'Neill DW. God and the pandemic: A Christian reflection on the coronavirus and its aftermath by N.T. Wright. Zondervan, 2020. Christ J for Global Health. Nov 2020; 7(4):63-65. https://doi.org/10.15566/cjgh.v7i4.473 (C) Author. This is an open-access article distributed under the terms of the Creative Commons Attribution License, which permits unrestricted use, distribution, and reproduction in any medium, provided the original author and source are properly cited. To vi $\epsilon$ a copy of the license, visit http://creativecommons.org/licenses/by/4.0/ 